\title{
Supervisory Analysis by Indonesian Sustainable Palm Oil Commission in Implementationof Sustainable Palm Oil Policy
}

\author{
Tarahani Novella, Mohammad Riduansyah \\ tarahanivella@gmail.com,moh.riduansyah@gmail.com
}

Faculty of Administrative Science, Universitas Indonesia, Indonesia ${ }^{1}$, Faculty of Administrative Science, Universitas Indonesia, Marzuki II, East Jakarta, Indonesia ${ }^{2}$

\begin{abstract}
The Indonesian government, through the Ministry of Agriculture, created a sustainable palm oil policy to control and protect Indonesia's palm oil production. This paper discusses supervision conditions relating to oil palm plantations, which consists of direct supervision, indirect supervision, internal supervision, and external supervision. The aim is to analyze the supervision of the implementation of sustainable palm oil policies by the ISPO Commission on oil palm companies in Indonesia with examples of PT. Lestari Tani Teladan. This study uses the theory of types of supervision by Manullang, with a qualitative approach. The results of the study show that the supervision carried out by the ISPO Commission on oil palm companies with the example of PT. Lestari Tani Teladan was not optimal due to various limitations of the ISPO Commission, while for other types of surveillance that involved several stakeholders had done well enough.
\end{abstract}

Keywords: Supervision; Palm Oil; Sustainable Palm Oil Policy; Indonesia Sustainable Palm Oil Commission, PT. Lestari Tani Teladan.

\section{Introduction}

Palm oil production develops at a very fast pace, as a result of an enormous number of CPO consumption all over the world. Palm oil plantations produce oil which not only can be used as cooking oil, but also as biodiesel, one of the alternatives for fuel, as nutrition in fodder, compost fertilizer, and as one of the ingredients for soaps and cosmetics. Based on the data from Badan Pusat Statistik (BPS), from the year 2013 to 2017, palm oil production has shown a significant increase. The data on palm oil production is shown below[1]:

Table 1.Crude Palm Oil (CPO) Production 2013 - 2017

\begin{tabular}{|cccccc|}
\hline Plantation Type & \multicolumn{5}{c}{ Plantation Production (Ton) } \\
\cline { 2 - 6 } & $\mathbf{2 0 1 3}$ & $\mathbf{2 0 1 4}$ & $\mathbf{2 0 1 5}$ & $\mathbf{2 0 1 6}$ & $\mathbf{2 0 1 7}$ \\
Palm Oil & 17.771 .30 & 19.072 .80 & 20.615 .90 & 20.155 .40 & 25.093 .40 \\
\hline
\end{tabular}

Table 1.1 shows the increase in palm oil production that is $1.07 \%$ by the year 2014 and $1.08 \%$ by the year 2015 . Even though in the year 2016, palm oil production went through a decrease of $1.02 \%$ in consequence of El Nino or extreme climate thus affected the Tandan Buah Segar (TBS) harvest season of palm plantations[2], it didn't give a 
significant effect, so the number of CPO production rose back in 2017.CPO production in Indonesia seems likely to keep expanding, as the area of palm oil plantations keeps on growing. The palm oil plantations scattered throughout Indonesia, such as in West Java province, Banten, Sumatra and Borneo Island, Central Sulawesi, South Sulawesi, South East Sulawesi, West Sulawesi, Gorontalo, Maluku, Papua, and West Papua. Amongst all those areas, the widest palm oil plantation in Indonesia in the year 2017 is located in Riau with atotal area of 2.42 million Hectares[3]. Several parties that governed the management of the plantations are the government, private entities, and citizens. The biggest plantations ownership is privately owned, in the second place is the government and lastly citizens. The percentage of private owned palm oil plantations is $55.24 \%$ that is $6,798,320 \mathrm{Ha}$, while the government-owned is $6.11 \%$ or $752,585 \mathrm{Ha}$, and lastly, citizens owned palm oil plantation take $38.64 \%$ of total plantations or 4,756,272 $\mathrm{Ha}[4]$.

As a sovereign state, Indonesia released a policy of sustainable palm oil certifications, which covered many aspects of good palm oil management and environmental protection. Indonesian Government issued the regulation also as a global stance toward sustainable palm oil through The Ministry of Agriculture in the form of sustainable palm oil plantation certification in the Ministerial Regulation Number 11/Permentan/OT.140/3/Tahun 2015 as revised from Agriculture Ministerial Regulation Number 19/Permentan/OT.140/3/Tahun 2011 about Indonesian Sustainable Palm Oil (abbreviated as ISPO).ISPO policy has been applied for six years since it was issued in 2011, but the number of companies abides by the policy still far from the designated target. This can be seen by the number of palm oil companies with ISPO certificate in 2018, which are 450 companies, still short 990 companies from the number target. The chart below shows companies with ISPOcertificates :

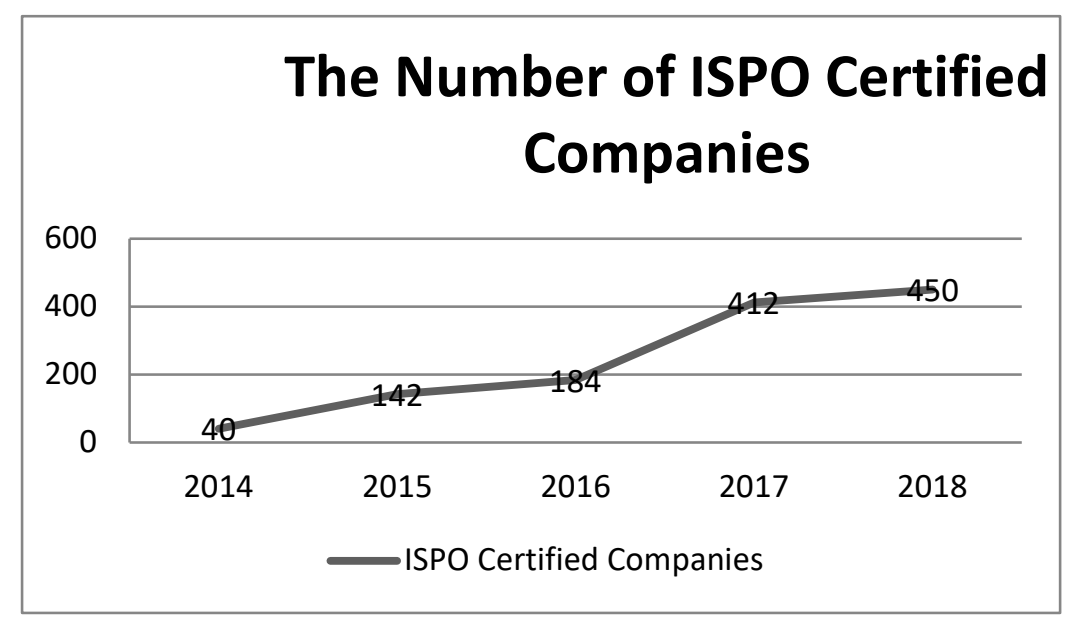

Fig. 1.Companies with ISPO Certificates

Based on chart 1.1, the number of palm oil companies with ISPO certificate are 450 companies, with the total of palm oil companies in the market are 1448 companies with total area 3,099,222 Ha, and total CPO production 11,031,934 million ton/year[5]. The companies which do not register on ISPO certification look the legal aspect of the certification is 
burdensome, as one of the requirement to get the certification is Hak Guna Usaha $(H G U)$ certification. Companies under ISPO commission's watch through the certification are still limited, thus this research's study case is one of the subsidiaries of Indonesian palm oil companyAstra Agro Lestari company, which already gotten its ISPO certificate.AAL has 39 subsidiaries with certificates[6].Among all 39, there is one company that becomes the object of this research, PT. Lestari Tani Teladan. The reason why Lestari Tani Teladan company becomes the research object because it has achieved more awards compared to other subsidiaries of Astra Agro Lestari. This also indicates that Lestari Tani Teladanhas good management. Therefore, PT. Lestari Tani Teladan,as a representative of Indonesian palm oil company with ISPO certificate becomes the object of this researchin analyzing the activities held by the ISPO Commission in implementing sustainable palm oil policy to palm oil companies.

\section{Literature Review}

Several literature reviews of this research are regarding public policy, public policy implementation, surveillance, supervision, andthe ISPO certification system. Public policy is defined as the Government's actions, designated objectives, and statementstoward certain problems, differing measures that had done, have done or failed to be done or implemented, and its explanation about several events that happened or didn't happen [7]. Andersondefined policy as a series of activities that have designated goals and objectives executed by one person or several actors in relation to certain issues in needof special attention [8]. Meanwhile, Woll [9]defined public policy as Government activities to solve society's problems, directly or through certain institutions, in relation to said problems. Referring to several definitions mentioned, thus public policy can be described as a series of actionswith designated goals, executed by individual or groups who cooperate to solve some problems. The policy can also be described as measures taken by the Government to include certain issues and public problems into policy agendas so that it can be implemented later. The public policy discussed in this research is sustainable palm oil policy, which is also known asIndonesian Sustainable Palm Oil governed by Agriculture Ministerial Regulation Number 11 Year 2015 under the authority of ISPO Commissionwhich is a Ministry of Agriculture's domain.

Implementation is a part of the process, which shows how a policy that has been arranged beforehand can be executed and achieved the designated objective. Mazmanian and Paul Sabatier [9]defined policy implementation as the execution of a policy, usually in the form of Regulation but also in other forms such as commandment or executive's or research institution's decision.Meanwhile, Jones stated[10]that implementation is the ability to form relationships out of causes and effects to further correlate between action and objective. While Donald S. Van Metter'sand Carl E.Va's opinion on the definition ofpolicy implementationispolicy implementation encompasses those actions by public and private individual (or group) that are directed at the achievement of objectives set forth in prior policy decisions. This includes both one time efforts to transform decisions into operational terms, as well as continuing efforts to achieve the large and small changes mandated by policy decision [11].

Thus, the core substance of the implementation of a policy is an understanding of what ought to happen after a program is applied or formulated. The understanding covered the efforts of policy administration and created a real impact on citizens[12]. Based on several 
definitions mentioned, the implementations of a policy are actions taken on a beforehand prepared policy. Implementation is an important stage which is a success factor of a policy.Surveillance is a personal data collection and processing, identified or not, with the purpose of engineering or management of the given data [13]. Surveillance described asclose watch kept on a person suspected of doing wrong,which means to surveil closely a person who potentially will do wrong. Based on the mentioned definitions, surveillanceis an activity to identify processed data to watch the threat of potential mistakes that can occur in the future[14]. One of the responsibilitiesofthe ISPO Commission to PT. Lestari Tani Teladan is surveillance, delegated to an independent certification institution, also surveillance and witnessto PT. AJA Sertifikasi Indonesia which responsible for the ISPO of PT. Lestari Tani Teladan.

Supervision as a systematic effort in setting the standard procedure of planning's objectives, the information system designs of feedbacks, comparison between real events with previous applied standards, definitions and measurements of deviances, and corrective actions needed to ensure all companies' sources effectively and efficiently used in order to achieve company goals [15]. Supervision is all efforts regarding operational activities observationin order to ensure all activities is aligned with the previously decided plan [16]. Based on several definitions of supervision mentioned previously, it can be concluded that supervision is an important activity thatinvolved observation, appraisal, and reporting on the whole operational activities in order to avoid or discover problems thatalready occurredor going to occur in the future. Other than that, supervision can be used as a tool to ensure the activities that occurareabiding by the standard or previously decided objectives.Supervision activities can be classified as[17]:

1. Direct and indirect supervision

Managers conduct direct supervision by looking, observing, and checking the site of company activities, while indirect supervision is conducted by studying and appraising oral or written reports.

2. Preventive and repressivesupervision

Preventive supervision aims in avoiding problems or deviations before they happen, so they can be easier to deal with in the future. Meanwhile,repressive supervision is supervision after audit activities that measure achievements based on the previously decided standard.

3. Internal and external supervision

Internal supervision classified as vertical and formal supervision that happened between the superintendent and his subordinate. Meanwhile, external supervision is supervision done by outside parties. This class of supervision is also called social supervision or informal supervision.

\section{Method}

This research uses a qualitative approach. Qualitative research is a process to gain a depiction of certain phenomena, to explore phenomena,and to provide an explanation of 
certain objectsof research [18].Meanwhile,John W. Creswellstated that the qualitative method is an investigation method to comprehend social problems based on the depiction and form of words to report informers' standpoints in a detailed manner, and arranged in scientific analysis [19].The qualitative approach utilized in order to get a deep understanding of supervision by the ISPO Commission in the effort of sustainable palm oil policy implementation (case studyPT. Lestari Tani Teladan).

The data collection method of this research is qualitative data collection. Research data gained by interviews, documentation, and literature reviews. The interviews conducted by gathering informationregarding the problems that will be discussed and involving several parties and using free questions depending on the informers' ISPO Commission, Academics, ISPO Judges, NGO, Certification Institution, and PT. Lestari Tani Teladan. Documentations of this research are notes and documents that can support the research data that consists of ISPO documents, data or information about companies with ISPO certification, other data from the companiesand etcetera. A literature review of this research is referring to and studying different theories about supervising.

\section{Result}

\subsection{Direct supervision by ispo commission to certification institution by surveillance and witness.}

ISPO Commission is a group of individuals mandated by the Indonesian Government to ensure that all palm oil companies are abiding by the Agriculture Ministerial Regulation Number 11/Permentan/OT.140/3/2015 ofIndonesian Sustainable Palm Oilcertification policy. Up until now, only a fewpalm oil companies in Indonesiaperform or fulfill the regulations of ISPO certifications, still far from the total number of companies that exist which can be caused by several reasons. One of them is the complex mechanism to earn the ISPO certificate that involving too many parties; local government, certification institution, and other shareholders. The involvement of too many parties is resulting in the elongated time needed for companies to earn the certification from the start of the certification process. The process of earning certification is approximately tenmonths based on the certification system stated in Permentan No.11 Year 2015, althoughin reality, the process can consume for almost two to three years. The long process contributed tothe low number of companies owning ISPO certificates and consequently contributed toproblems aroused from palm oil mismanagement.Up until now, the commission only has the authority to supervise 450 palm oil companies, while the other 913 companies arestill long in the certification process. So the direct supervision of the ISPO Commission had been delegated to PT. AJA Sertifikasi Indonesia in observing and auditing the content of companies' reports.

ISPO Commission directly supervises the certification institutions which cooperate with ISPO Commission for ISPO certification. Direct supervision is conducted byISPO Commission through surveillance and witness to the certification institutions auditing the palm oil companies. The difference between surveillanceandwitness is while surveillance is conducted by ISPO Commission once a year through surveillanceappraisal form, the witness is conducted randomly, with no fixed date, by observing, seeing, and concluding. This indicates that ISPO Commission does not have a direct relationship with palm oil companies from their certification application through surveillance activities in the five years of their ISPO certificate ownership.From surveillance and witness, certification institutions can maintain or lose their ISPOcertification authorization if misconducts are found. One of the certification institutions becomes the object of this research that is PT. AJA Sertifikasi Indonesia, which 
supervises on PT. Lestari Tani Teladan. ISPO Commission is doing surveillance and witness on PT. AJA Sertifikasi Indonesia. The results on AJA's surveillance and witnesses indicate that they rightly conduct the auditingand abide by the Permentan ISPO.

Certification institution appraised as a whole following trough the evaluation instrument of the ISPO Commission.The result of the appraisal will decidewhetherthe cooperation between ISPO Commission and certification institution is being continued or not. Since the first time of the partnership in 2014, PT. AJA Sertfikasi Indonesia has never been suspended. ISPO Commission's evaluation ofthem has been in concordance with evaluation requirements and evaluation form. The completed evaluations from surveillance dan witness will conclude that the certification institution is credible. In the end, it will encourage PT. Lestari Tani Teladan as the company that AJA Sertifikasi Indonesia auditedto abide by rules.Since it was firstinaugurated in 2011, ISPO has met many constraints and shortcomings in doing the once year surveillance and the random witness. Only a few certification institutions and palm oil companies that directly observed and evaluated by theISPO Commission haveactually implemented the correct ISPO.This might be caused by the big number of companies registered, all 450 companies have tobe ensured that they abide by Permentan No. 11 Tahun 2015 of ISPO. The obstacles in doing direct supervision are finding a time to meet between certification institutions and ISPO secretariat and the big cost needed for direct supervision, as palm oil plantations are located inremote areas and needed extratransportation andaccommodation cost. The constraints faced by the ISPO Commission in doing surveillance and witnessto all certification institution partners are:

\section{The Limited Sources Of ISPO Commission}

One of the many important factors of good supervising practice is the availability of human resources to supervise[20]. Today theISPO Commission is under Directorate of Plantations, this indicates that ISPO Commission is onlya small scale commission that has an interlinked system withDirectorate of Plantations. The number of employees in the ISPO Commission isn't as many as other commissions. The number of members in the ISPO Secretariat is 11 people, while there are 14 ISPO Commissionfrom several Ministries and other partnering government institutions such as Ministry of Environment and Forestry, National Land Authority, et cetera. The supervisor team, as the team who verifies reports in the certification application process consists of 19 people.Meanwhile tasks such as verification, surveillance, and witness activities, also administration works are done by ISPO secretariat, thus judging from the composition and the total number of employees there is a shortcoming where the number of commission and supervisors is bigger than secretariat, while commission and supervisor team have fewer tasks and activities than the secretariat. The small number of secretariat employees is impacting their capacity to accommodate reports and other activities. There is noStandard Operating Procedure(SOP) regulatingsurveillance and witness.

In every activity including supervising, there should be a fundament or procedure so that the activity is conducted correctly and following the applicable rules. ISPO Commission does not have a standard operating procedure (SOP), which can be referred to in any surveillanceand witness activity. The commission doesn't own a designated SOP to regulate those activities. The availability of SOP is important to an organization in order to have guidelines or rules for their activities so they can be carried out easier. ISPO Commission only assigns Permentan Number 11/permentan/OT/2015 as a fundament for all of their activities. So the ISPO Commission refers to Permentan 11 year 2015 about ISPO and sees if each regulation is correctly carried out or not. The ISPO Commission's way of thinking is that by gaining ISPO certificates, the companies have to conduct their activities following the correct standards 
applied. Meanwhile, there is a big risk of misconduct from their future activities by not having SOP Specified for Regulating Surveillance and Witness[21].

In every activity including supervising, there should be a fundament or procedure so that the activity is conducted correctly and following the applicable rules. ISPO Commission does not have a standard operating procedure (SOP), which can be referred to in any surveillance and witness activity. The commission doesn't own a designated SOP to regulate those activities. The availability of SOP is important to an organization in order to have guidelines or rules for their activities so they can be carried out easier. ISPO Commission only assigns Permentan Number 11/permentan/OT/2015 as a fundament for all of their activities. So the ISPO Commission refers to Permentan 11 year 2015 about ISPO and sees if each regulation is correctly carried out or not. The ISPO Commission's way of thinking is that by gaining ISPO certificates, the companies have to conduct their activities following the correct standards applied. Meanwhile, there is a big risk of misconduct from their future activities by not having a SOP specified for regulating surveillance and witness

There is No Training or Knowledge Update for Auditors of Certification Institutions.

Implementation of ISPO with the focus of its sustainability has an objective so that the companies can operate despite all the changes in the environment and natural resources. Auditors have a responsibility to ensure ISPO carried out by the applied rules, and always have the updated current knowledge based on the current conditions in the future. Knowledge update activities of auditors in order to update the knowledge on natural resource management standard is very important to carry out. Turf and forest in the future are prone to have changes in their soil or species living inside them. That is whyknowledge update is needed to carry out once a year with the purpose to adapt to the changes in relation to the ISPO certification activities. The regulations are also updated changes based on changes in the ecosystem. Today the Commission hasn't carried out knowledge update for partnering auditors, as it is still on the planning stage.

\subsection{Indirect Supervision by ISPO Commission Through Certification of PT. Lestari Tani Teladan}

The relationship between the ISPO Commission with palm oil companies is indirect, with intermediary from certification institutions. ISPO implementation of PT. Lestari Tani Teladan (LTT) in Central Sulawesi is fully supervised and managed by PT. AJA Sertifikasi Indonesia a certification institution. The result report of all activities will be given to ISPO Commission as the party who has authorization in deciding acts, other than that the Commission will also ask for insufficiency in the report through certification institutions. This is the very definition of indirect supervision. Indirect supervision is supervising activitywhich conducted by studying and appraising oral or written reports. ISPO Commission through ISPO Secretariat and Supervising Team will study each report given by PT. AJA Sertifikasi Indonesia in their practice of consistence supervision of ISPO implementation of LTT for five years before the certificate expires. The commission will do report evaluation and hands it to AJA which will deliver the feedbacks to LTTabout what can be done better. PT. Lestari Tani Teladan,the object of this research, was first receivedthe act of surveillancein $7^{\text {th }}-9^{\text {th }}$ of March 2018, with total auditors three people, andone reviewer.The auditing was conducted in nine working days. The indirect supervision by mandating an intermediary institutionfor supervising activities is very feasible as the ISPO Commission structure which is under Ditjenbun is small in scale so it has limited resources and with the form of ISPO policy in the certificate. 
On palm oil companies, the surveillance is done for five years before the ISPO certificate is expired, one of them is LTT. LTT received the ISPO certificate in March 2017, so from March 2017 to March 2018, LTT has possessed the certificate for one year. The result of surveillanceon LTT in their first year shows that the whole company's process management is consistent with the principals and requirements of ISPO. LTT is obligated to consistently implemented ISPO for five years until re-certification. During the surveillance process, the main aspect of appraised is the changes in previous years with the current year. In surveillanceactivities, certification institution will evaluate on-site to see changes made since certificate possession and companies' consistency in implementing seven principal of ISPO. The result of surveillance activity is a description of findings on site both for what is done correctly or wrong. The misconducts found in LTT were in several principles, they are first, second, fourth, fifth, and sixth principals[22]. Among the said principles, the most misconductsfound were in the fourthprinciplethat is about environmental management and monitoring. The findings were mostly about hazardous and toxic waste management and alsoflora and fauna watching. Other findings in other principles can only be found in one or two misconducts. Waste management findings were mostly due to misconducts of transporters, waste collectors and waste management agents. Those shareholders are under license of the Ministry of Environment, which one of the rules is the prohibition to use the service from all three, as fraud will be prone to happen. Other than that, the location of Sulawesi which is more remote than other areas is becoming the cause for the difficulty in finding vendors or contractors. Because of said obstacles found in the site of LTT company, other palm oil companies located in $\mathrm{C} 1$ area are most likely to undergone the same situation. The ISPO commission hadverified a surveillancereport of LTT handed by AJA Sertifikasi and declared that LTT passed the first stage of surveillance. Secretariat had approved the surveillancereport as it wascomplete and correct. ISPO Commission assigned one person to be a report reviewer. As LTT surveillance report had been completed, ISPO Commission as an authorized party declared LTT completed its first-year ofsurveillance and that they implement ISPO principles and requirements. In the verification process, the time frame is needed so that other activities of certification institutions can be done on time. This is important because there are other clients of PT. AJA,not only PT. Lestari Tani Teladan.The absence of a time frame in doing verification will result in stacks of undone surveillancereports accumulated at certification institutions and ISPO Commission Secretariate. This will also result in legal actions toward companies' misconduct as theiralready submitted surveillance reports are abandoned and unverified. Verification represented by one reviewer fromthe ISPO Secretariat whose task is to ensure the evaluation of criteria referring to ISPO principles. The time needed to finish the verification as been said before is depending on the amount of other works, which can consume two to three months.Punishmentin the form of certificate revocation for companies' misconduct during surveillanceis an administrative legal action. This indicates that ISPO implementation is limited only to certificate document confirmation and not legal enforcement effort toward problems caused by palm oil processing. One of the examples is, during surveillance, if forestland misuse or deforestation are found, then law applied should be criminal law on deforestation or forest fire. But in reality, the enforcement of ISPO if that happens is only palm oil companies' ISPO certificate revocation.

\subsection{Internalsupervision through internal audit on PT. Lestari Tani Teladan}

The internal audit of LTT not only in respect of site activities, but also audit on finance, inspectorate audit, and ISPO internal assessment[23]. Many aspects is needed to be supervised 
by the company making the need for the internal auditors is increasing. Today all training on palm oil businesses conducted by training institutions selected by ISPO Commission. The name of the training which is a cooperation between the ISPO Commission and LPP isISPO auditor training.AAL's internal auditprogram is called Assessment Internal (Self Assessment). This activity is conducted to prepare PT. Lestari Tani Teladan as a subsidiary for audit by certification institution. Assessment of internal audit regarding ISPO is done by referring to previous surveillance reports from other subsidiaries.

The instrument of assessment is only referring to previous surveillance reports. Meanwhile, other internal audits are referring to reports based on their divisions' such as finance division and inspectorate supervision. By continually conducting internal audits every year, the company also preventing the employees so that they will not do misconduct regarding ISPO in their activities.Internal audit on all subsidiaries indicates that the company management of LTT undergone several stages of supervision started frominternal assessmentto supervision by certification institution. LTT has practiced the ISPO system internally. This shows that internal audit is very beneficial for the company and contributing to good governance.In order to support ISPO auditing activities, all palm oil companies are suggested by ISPO Commission to form special division for ISPObusinesses. This division is obliged to be formed in order to helpthe ISPO process and alsoto accommodate activities in relation toISPO auditing. ISPO organization structure of PT. Lestari Tani Teladan consists of the person in charge or administrator who responsible for ISPO implementation in LTT and to receive and issue documents regarding ISPO, and then there is a coordinator assisted by a secretary, the coordinator is a headof eight PICs foragronomy, conservation, SHE, community development, legal, administration, and manufacture. The availability of organization structure proved that LTT has obeyed the rule for having a special divisionfor ISPO.

\subsection{External Supervision By External Parties}

External supervision is also known as informal or social supervisionExternal supervision is done by a community or institution outside the organization with a different perspective on applied policy. In the implementation of the ISPO certification policy, external parties consist of Non-Government Organization (NGO), palm oil companies association, and society.

Involvement of Non-Government Organizations. ISPO Commission mandated NGOs as part ofthe evaluation team to verify reports given by certification institutions, as stated in Keputusan Direktur Jenderal Perkebunan Selaku Ketua Komisi Perkebunan Kelapa Sawit Berkelanjutan Indonesia Number 211/Kpts/OT.050/6/2018 about membership of evaluation team of ISPO Commission. In reality, NGOs involvement are still limited, this because the number of NGOs focusing on palm oil generated problems are informers' in number, with different objectives and perspective. One of which is Sawit Watch, one of NGO focusing on palm oil, which does not involve in ISPO activities and has no communication with LINKS. We can see from the example above that NGOs involvedin the ISPO system is limited, as the Commission is only mandated one NGO and not involving other NGOs. NGOs involvement in the arrangement of ISPO certification amendment started when they were invited to do revision on Permentan Number 11 year 2015. NGOs opinions were written in disposition, roadmap, and involved inhearing[24]. The Commission invited NGOs to give feedback on every business regarding palm oil management. Shareholder involved isgovernment, palm companies, and NGOs. The shareholders arranged their own drafts which then submitted to ISPO Commission. Submitted drafts originally will be followed up by ISPO Commission, although after the policy was applied, there is no update or feedback from ISPO Commission. 
FWI issued several publications that can be accessed by citizens about six years of ISPO policy.

Involvement of GAPKI Association.Until 2018, the number of GAPKI membersis approximately 700 companies with those who already have ISPO certificates are 297 companies, one of them is PT. Lestari Tani Teladan which is a member since 2015. GAPKI doesn't have access to watch for all 297 companies with a certificate to see if they actually implement ISPO. Today the role of GAPKI is encouraging and ensure that their members to get the ISPO certificates. While for supervising activities, GAPKI does not responsible to supervise its members on ISPO implementation.GAPKI Association has several affiliations throughout Indonesia, and in those affiliations, they socialize and encourage companies especially their members to get ISPO certificate. Socialization held annually at the least with the speaker from ISPO Commission or other authorized parties. In socialization events, companies that are facing problems in the ISPO system will be data collected and GAPKI will help them solve the problems and discuss the things that can be done by their members.

Involvement of Society. One of the direct supervision agents in plantation activities arenearby residents. Residents tend to know better the actual condition of palm oil plantation management activities as they can see it with their own eyes. Usually, society participation is done in the way that they have their own judgment and deliver it to companies' employees in the plantation site. According to PT. AJA Sertifikasi Indonesia, such direct suggestions happened before when they were auditing, and they had to interview nearby residents. The complaints delivered were becoming part of certification institutions' judgment inthe audits to be checked and confirmed with companies' employees. Society tends to seek possibly gained benefits or advantages from the companies for theireveryday life through Corporate Social Responsibility (CSR)activities[25]. The Corporate Social Responsibility programis done by PT. Lestari Tani Teladan's subsidiary in Central Sulawesi in the effort to meet the need of nearby citizens using bottom-up planningwere building water supply network 3.000 meters long from a spring at Desa Minti Makmur to SMAN 1 Rio Pakava in the year 2014, free circumcision program, providing educational facilities of SD Lestari Tani Teladan, and Posyandu Lestari Tani Teladan.

\section{Conclusion}

Supervising activities held by ISPO Commission on palm oil companies up until now is limited to a certain number of companies, the time needed to fulfill the flow of certification process is quite long, especially in the legal process stages, correlated with local government. Based on this research, the ISPO Commission is doing direct supervision on palm oil companies through certification institution intermediary. In the effort to ensure the palm oil companies are implementing ISPO correctly, the Commission directly supervisesthe certification institutionand evaluatethe audit reports done by surveillanceand witness. Obstacles and problems found in the process by the ISPO Commission indicate that direct supervision has not yet optimal. That means the ISPO Commission as a government institution does not have a very strong integration. On the other hand, the indirect supervision and other kinds of supervision have been done well based on the descriptionsgained during the research at PT. Lestari Tani Teladan. 


\section{Recommendation}

ISPO implementationas a sustainable system needs multiple parties involvement, in order to achieve good ISPO implementation it needs several improvements in ISPO Commission, such as:

1) ISPO Commission should be able to encourage local government to simplify permission policy, because the main obstacle found in fulfilling target on a number of companies having certification is the time needed for permission to be earned, and consequently elongates the time of auditing by certification institutions.

2) In order to solve the limited witness and surveillance activities on certification institutions, the ISPO Commission needs to have legal justificationother thanAgriculture Ministerial Regulation, which prone to revision after Cabinet reshuffle, it can also obtain bigger funds from APBN with a bigger composition of human resource on the secretariat.

3) The ISPO Commissionneeds to construct SOP which regulates surveillance and witness activitiesso that they do not only referred from the ISPO certification system.

4) In order to support ISPO implementation, the Commission should not only involve NGO in Evaluation Team, but also other NGOs in Indonesia to achieve a more effective decrease in deforestation.

5) GAPKI associationas a member of the ISPO Commission should be able to have power on helping palm oil companies by providing solutions to their problems in applying to ISPO certification.

Acknowledgements. Authors would like to thankful all correspondents who have been provided data and informations to finished this research. They are PT. Astra Agro Lestari (Head Of PT. Lestari Tani Teladan), Indonesian Sustainable palm Oil Commission, Expert Figure, Assessment Team,NGO, PT. AJA Sertifikasi Indonesia as Independent Certification Agency.

\section{References}

[1] Badan Pusat Statistik. Statistik Kelapa Sawit Indonesia. (2017) https://www.bps.go.id/publication/2018/11/13/b73ff9a5dc9f8d694d74635f/statistik-kelapa-sawitindonesia-2017.html

[2] Mukti, S. Semester I 2018 Minyak Kelapa Sawit Tertekan. 2018 https://gapki.id/news/5670/semester-i-2018-pasar-minyak-sawit-indonesia-tertekan(20 November (2018).

[3] Litbang Kementerian Pertanian. Kondisi Lahan Kelapa Sawit. Jakarta: Kementerian Pertanian (2017) www.litbang.pertanian.go.id

[4] Demitria, D. Statistik Perkebunan Indonesia 2015 - 2017, Jakarta: Direktorat jenderal perkebunan (2017) http://ditjenbun.pertanian.go.id/tinymcpuk/gambar/file/statistik/2017/Kelapa-Sawit-20152017.pdf

[5] Nuryati L.Outlook KelapaSawit. Jakarta: Pusat Data danSistemInformasiPertanian (2016).http://epublikasi.setjen.pertanian.go.id

[6] PT. Astra Agro Lestari. 2018 Towards Sustainability Stewardship (2019) https://www.astraagro.co.id > 2019/04 > Sustainability-report-2018-web-1

[7] Dunn, W.N. AnalisisKebijakanPublik. Yogyakarta: GadjahMada University Press (2003)

[8] Agustino, L. Dasar-Dasar Kebijakan Publik. Bandung: Alfabeta (2006)

[9] Tangkilisan,H. Implementasi Kebijakan Publik. Yogyakarta:Lukman Offset (2003)

[10] Nawawi, I. Public Policy. Analisis, Strategi Advokasi Teori dan Praktek. Surabaya: PMN. (2009) 
[11] Widodo,J, Analisis Kebijakan Publik. Malang: Bayumedia Publishing.(2010)

[12] Herabudin. StudikebijakanPemerintahdariFilosofikeImplementasi. Bandung: PustakaSetia (2016)

[13] Lyon, D.Surveillance Society: Monitoring Everyday Life. Philadelphia: Open University Press (2001)

[14] Hornby,A. The Oxford Student's Dictionary : Survaillance. Oxford University Press. (1990)

[15] Harahap, S. Sistem Pengawasan manajemen (management control system). Jakarta:Quantum (2001)

[16] Siagian P. Sondang. Manajemen Stratejik. Jakarta: Bumi Aksara. 2011.

[17] Manullang, M. Dasar - Dasar Manajemen. Yogyakarta: Gajah Mada University Press.2015.

[18] Basrowi, Memahami Penelitian Kualitatif. Jakarta: Rineka Cipta. 2008.

[19] Craswell, J.W. Research Design (International Student Edition):Qualitative, and Mix Methode Approaches. Sage Publication US Public. 2013.

[20] Lawrence T, Weber J. Business and Society; Stakeholders, Ethics, Public Policy. New York: McGraw-Hill Companies Inc.2015.

[21] Grussenmeyer, Sr. Axtension associate. Developing Effective Standard Opeating Procedure. Cornell University (2016) http://www.ansci.cornell.edu/pdfs/sopsdir.pdf.

[22] PT. AJA Sertifikasi Indonesia. Laporan Surveillance PT. Lestari Tani Teladan. 2018.

[23] PT. Astra Agro Lestari. Dokumen Hasil Internal Assessment.2018.

[24] Forest Watch Indonesia. Diskusi dan Konsultasi Para Pihak untuk Studi Implementasi ISPO. Bogor: FWI Publication.(2018) http://fwi.or.id/diskusi-dan-konsultasi-para-pihak-untuk-studiimplementasi-ispo/

[25] PT. Astra Agro Lestari. Laporan Tahunan Corporate Social Responsibility. (2018. 